The University of Maine

DigitalCommons@UMaine

Marine Sciences Faculty Scholarship

School of Marine Sciences

12-29-2009

\title{
High-Frequency in Situ Optical Measurements During a Storm Event: Assessing Relationships Between Dissolved Organic Matter, Sediment Concentrations, and Hydrologic Processes
}

\author{
J.F. Saraceno \\ B. A. Pellerin \\ B.D. Downing \\ Emmanuel Boss \\ University of Maine - Main, emmanuel.boss@maine.edu \\ P. A.M. Bachand \\ See next page for additional authors
}

Follow this and additional works at: https://digitalcommons.library.umaine.edu/sms_facpub

\section{Repository Citation}

Saraceno, J. F.; Pellerin, B. A.; Downing, B. D.; Boss, Emmanuel; Bachand, P. A.M.; and Bergamaschi, B. A., "High-Frequency in Situ Optical Measurements During a Storm Event: Assessing Relationships Between Dissolved Organic Matter, Sediment Concentrations, and Hydrologic Processes" (2009). Marine Sciences Faculty Scholarship. 54.

https://digitalcommons.library.umaine.edu/sms_facpub/54

This Article is brought to you for free and open access by DigitalCommons@UMaine. It has been accepted for inclusion in Marine Sciences Faculty Scholarship by an authorized administrator of DigitalCommons@UMaine. For more information, please contact

um.library.technical.services@maine.edu. 
Authors

J. F. Saraceno, B. A. Pellerin, B. D. Downing, Emmanuel Boss, P. A.M. Bachand, and B. A. Bergamaschi 


\title{
High-frequency in situ optical measurements during a storm event: Assessing relationships between dissolved organic matter, sediment concentrations, and hydrologic processes
}

\author{
John Franco Saraceno, ${ }^{1}$ Brian A. Pellerin, ${ }^{1}$ Bryan D. Downing, ${ }^{1}$ Emmanuel Boss, ${ }^{2}$ \\ Philip A. M. Bachand, ${ }^{3}$ and Brian A. Bergamaschi ${ }^{1}$ \\ Received 28 February 2009; revised 14 August 2009; accepted 11 September 2009; published 29 December 2009.
}

[1] Dissolved organic matter (DOM) dynamics during storm events has received considerable attention in forested watersheds, but the extent to which storms impart rapid changes in DOM concentration and composition in highly disturbed agricultural watersheds remains poorly understood. In this study, we used identical in situ optical sensors for DOM fluorescence (FDOM) with and without filtration to continuously evaluate surface water DOM dynamics in a $415 \mathrm{~km}^{2}$ agricultural watershed over a 4 week period containing a short-duration rainfall event. Peak turbidity preceded peak discharge by $4 \mathrm{~h}$ and increased by over 2 orders of magnitude, while the peak filtered FDOM lagged behind peak turbidity by $15 \mathrm{~h}$. FDOM values reported using the filtered in situ fluorometer increased nearly fourfold and were highly correlated with dissolved organic carbon (DOC) concentrations $\left(\mathrm{r}^{2}=0.97\right)$, providing a highly resolved proxy for DOC throughout the study period. Discrete optical properties including specific UV absorbance $\left(\mathrm{SUVA}_{254}\right)$, spectral slope $\left(\mathrm{S}_{290-350}\right)$, and fluorescence index (FI) were also strongly correlated with in situ FDOM and indicate a shift toward aromatic, high molecular weight DOM from terrestrially derived sources during the storm. The lag of the peak in FDOM behind peak discharge presumably reflects the draining of watershed soils from natural and agricultural landscapes. Field and experimental evidence showed that unfiltered FDOM measurements underestimated filtered FDOM concentrations by up to $\sim 60 \%$ at particle concentrations typical of many riverine systems during hydrologic events. Together, laboratory and in situ data provide insights into the timing and magnitude of changes in DOM quantity and quality during storm events in an agricultural watershed, and indicate the need for sample filtration in systems with moderate to high suspended sediment loads.

Citation: Saraceno, J. F., B. A. Pellerin, B. D. Downing, E. Boss, P. A. M. Bachand, and B. A. Bergamaschi (2009), High-frequency in situ optical measurements during a storm event: Assessing relationships between dissolved organic matter, sediment concentrations, and hydrologic processes, J. Geophys. Res., 114, G00F09, doi:10.1029/2009JG000989.

\section{Introduction}

[2] Dissolved organic matter (DOM) is an integral part of aquatic biogeochemistry and affects nutrient cycling, ecosystem productivity, UV light penetration, heavy metal transport and drinking water quality [e.g., Williamson et al., 1999]. Local- to regional-scale forcing such as climate variability and land use change are key drivers of DOM dynamics in many ecosystems and are therefore critical to predicting and managing water quality. Several recent studies have shown the importance of short-term hydrologic events in the flux and composition of DOM in agricultural watersheds [Dalzell et al., 2005; Royer and David, 2005;

\footnotetext{
${ }^{1}$ U.S. Geological Survey, Sacramento, California, USA.

${ }^{2}$ School of Marine Sciences, University of Maine, Orono, Maine, USA.

${ }^{3}$ Bachand and Associates, Davis, California, USA.
}

Copyright 2009 by the American Geophysical Union. 0148-0227/09/2009JG000989
Hernes et al., 2008; Vidon et al., 2008; Wilson and Xenopolous, 2009]. However, considerable uncertainty remains regarding the timing, magnitude and composition of episodic DOM transported from human-modified and natural watersheds to freshwater environments. Understanding DOM dynamics during storm events requires sampling at intervals that capture the hydrologic, physical and biological variability in water quality [Kirchner et al., 2004; Hood et al., 2006]. Therefore, the application of in situ optical sensors to storm event DOM dynamics is of great interest given the importance of rainfall-runoff and altered flow paths on organic matter transport and composition [Schuster et al., 2008]. Laboratory studies have shown the potential for absorbance and fluorescence measurements to differentiate between terrestrial and aquatic sources of DOM, as well as to assess physical, chemical and biological alterations of organic matter concentration and composition [e.g., Coble, 1996; Vodacek et al., 1997; Del Castillo 
et al., 1999; Twardowski and Donaghay, 2002; Boss and Zaneveld, 2003]. The use of in situ optical sensors for fluorescent DOM (FDOM) has largely been limited to marine systems, but a small number of recent studies have also demonstrated the utility of these tools in freshwater environments [Spencer et al., 2007; Downing et al., 2008; van Verseveld et al., 2008].

[3] The application of in situ sensors originally developed for marine studies to riverine systems requires the validation of several key assumptions prior to widespread use. One fundamental assumption of high-frequency in situ DOM optical measurements is that the sensor responds only to dissolved constituents. Sediment interference of unfiltered in situ DOM measurements is a potential limitation for their use in freshwater environments because elevated particle concentrations can contribute significantly to the attenuation coefficient, potentially biasing a measurement intended only for DOM. Belzile et al. [2006] reported that suspended sediments did not interfere with the utility of DOM fluorescence as a proxy for the dissolved absorption coefficient $\left(\mathrm{a}_{370}\right)$ and DOC in freshwater and coastal systems, suggesting the ability to make representative unfiltered measurements in a range of environments. However, the low sediment concentrations in their study $\left(<35 \mathrm{mg} \mathrm{L}^{-1}\right)$ are not representative of many rivers, particularly during storm events in human-modified watersheds. While unfiltered measurements have the advantage of being simpler and more cost effective to implement, additional information is needed to assess sediment interference with in situ optical measurements of dissolved constituents.

[4] The goal of our study was to quantify the timing, composition and concentration of DOM exported from the agricultural Willow Slough watershed over a 4 week period characterized by a $4 \mathrm{~cm}$ rainfall event. Specific objectives were to: (1) quantify temporal patterns in DOM dynamics during a storm event using in situ optical sensors, (2) assess relationships between in situ FDOM and laboratory optical properties indicative of DOM source and composition, and (3) test the hypothesis that differences between filtered and unfiltered FDOM values were negligible during a storm event characterized by increased DOM concentrations and turbidity. Highly resolved time series are critical to accurately quantify the rate and magnitude of changes in DOM composition and concentration during storm events and assessing impacts on aquatic ecosystems and drinking water quality.

\section{Materials and Methods}

\subsection{Site Description}

[5] Storm event sampling was conducted in the Willow Slough watershed, a $415 \mathrm{~km}^{2}$ agriculturally dominated catchment in the western Sacramento Valley of California (Figure 1). The study area encompasses the eastern slope and low-lying foothills of the inner Coast Range which are characterized by steep slopes (mean $=25 \%$ ) and the dominance of grassland vegetation with intermittent valley oaks. Grassland headwaters account for $31 \%$ of the total watershed area, while the farmed, flat alluvial plain (mean slope $=1 \%$ ) makes up the eastern two-thirds of the watershed. The dominant crop types are alfalfa, irrigated pasture and grass, tomato, orchard and rice (Figure 1).
Urban land use is a small component of the watershed area, accounting for $3 \%$ of the total. The Mediterranean climate is characterized by cool winters (mean $=8.2^{\circ} \mathrm{C}$ ) and warm summers (mean $=22.8^{\circ} \mathrm{C}$ ), with annual rainfall ranging from approximately 45 to $86 \mathrm{~cm}$ along a west-east gradient in the watershed with $95 \%$ of rainfall occurring between October and April.

\subsection{In Situ Measurements}

\subsubsection{Optical Measurements}

[6] Water samples and in situ data were collected between 15 February and 18 March 2008 at the mouth of the Willow Slough Watershed (Figure 1, black circle). In situ data were collected using two separate optical systems, one with a filtered flow path and one with and unfiltered flow path. The unfiltered system was deployed in the channel thalweg, and the filtered system was deployed on the channel bank approximately $100 \mathrm{~m}$ downstream using a positive displacement pump mounted in the thalweg for sample delivery to the instruments. The unfiltered system consisted of a WETLabs (Philomath, OR) flow-through WETStar fluorescent dissolved organic matter (FDOM) fluorometer and a WETLabs model DH-4 data logger strapped to a stainless steel cage, with water $0.5 \mathrm{~m}$ above the channel bed drawn through an $80 \mu \mathrm{m}$ mesh screen via a submersible in-line pump prior to measurement [Downing et al., 2009]. The FDOM fluorometer, with a $7 \mathrm{~mm}$ optical path length, uses a single excitation/emission pair (370/460 nm; with 10 and $120 \mathrm{~nm}$ excitation/emission band pass, respectively) to estimate the quantity of fluorescent, humic-like DOM (peak C [Coble, 1996]). This (single ex/em pair) sensor may not successfully predict DOC concentration in situations where DOM transformations are dominated by changes in nonhumic like material such as tyrosine-like DOM [Coble, 2007]. In general, however, peak $C$ is appropriately suited for studies interested in tracking DOM related to anthropogenic activities and agricultural land use [Coble, 2007]. Response is linear $\left(\mathrm{r}^{2}=0.99\right)$ up to $500 \mathrm{ppb}$ quinine sulfate equivalents (QSE) (per manufacturer), or about three times the maximum values present in this data set. Data were collected at $1 \mathrm{~Hz}$ for $30 \mathrm{~s}$ every hour over the course of the study period, with the values for the last $10 \mathrm{~s}$ of each sampling period averaged to yield a single hourly data point. Conversions from raw voltage to QSE followed equation (1):

$$
\mathrm{ppb} \mathrm{QSE}=\left(\mathrm{V}_{\mathrm{sig}}-\mathrm{V}_{\mathrm{cw}}\right) * \mathrm{SF},
$$

where $1 \mathrm{ppb}$ QSE is the fluorescence of $1 \mathrm{ppb}$ QS in $0.1 \mathrm{~N}$ $\mathrm{H}_{2} \mathrm{SO}_{4}, \mathrm{~V}_{\text {sig }}$ is the output sample voltage of the FDOM fluorometer, $\mathrm{V}_{\mathrm{cw}}$ is the voltage of a clean water blank, and $\mathrm{SF}$ is an instrument specific scaling factor with units of $\mathrm{ppb}$ $\mathrm{QSE} /\left(\mathrm{V}_{\mathrm{sig}}-\mathrm{V}_{\mathrm{cw}}\right)$. The manufacturer supplied the and engineering unit scaling factor, SF, to convert voltage values into quinine sulfate equivalents. The manufacturer supplied clean water offset voltage $\left(\mathrm{V}_{\mathrm{cw}}\right)$ was checked against an inhouse ultra purified water system and subsequently used to blank the in situ fluorometer.

[7] The filtered instrument package was deployed on the channel bank to allow for access to the instruments and filter housing during high-flow periods. Sample water was pumped from approximately $1 \mathrm{~m}$ above the channel bottom 


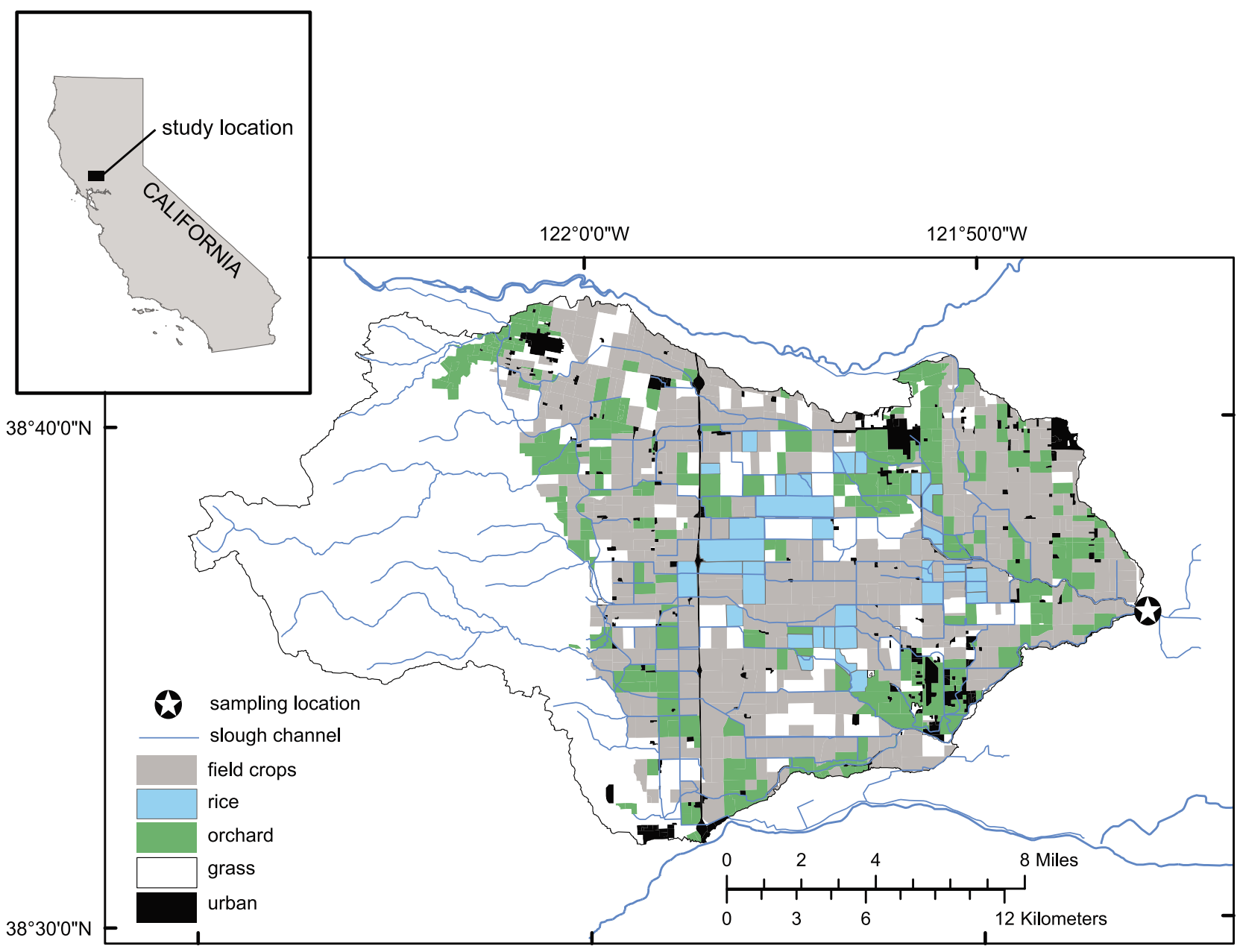

Figure 1. Location of the Willow Slough agricultural watershed and the watershed outlet sampling location (black circle with inscribed white star).

near the center of the channel through prerinsed Tygon tubing and $10 \mu \mathrm{m}$ and $0.2 \mu \mathrm{m}$ membrane filters (Osmonics Memtrex, $0.25 \mathrm{~m})$. Filtered water passed through the same instrument configuration as the unfiltered package, but the instrumentation was housed in a barrel filled with discharged surface water to maintain instrument temperature. Data were collected at hourly intervals and processed as described previously for the unfiltered system. Filtered data are not presented over the period of 28 February to 6 March due to filter clogging and instrument maintenance. Based on system geometry (tube diameter, and length), flow rates above $2 \mathrm{~L} \mathrm{~min}-1$ for a period of $3 \mathrm{~min}$ were sufficient to clear the system of stagnant water prior to measurement. Data are not presented for the unfiltered fluorometer from 6-10 March because high channel sedimentation rates necessitated the removal and transport of equipment from the site for maintenance.

\subsubsection{Ancillary Measurements}

[8] Water temperature, specific electrical conductance (SC), dissolved oxygen (DO), and turbidity were measured in situ using a YSI Model 6920 sonde (YSI, Yellow Springs, $\mathrm{OH}$ ) deployed adjacent to the in situ unfiltered system. Turbidity (scattering at $90^{\circ}$ and $830-890 \mathrm{~nm}$ ) was measured using the YSI model 6136 probe calibrated with optically clean water and polymer standard and is reported in formazin nephelometric units (FNU) [Anderson, 2004]. The instrument was cleaned and calibrated twice during the study period, resulting in record gaps lasting from several hours (29 February) to several days (6-10 March). Surface water stage and discharge data presented here were measured approximately $1.5 \mathrm{~km}$ downstream of the water quality sampling location using a pressure transducer and a rating curve established between 2006 and 2008. Precipitation volume was recorded at the headwaters and watershed mouth using HOBO tipping bucket rain gauges (Onset Computer Corporation, MA).

\subsection{Discrete Samples}

[9] Prestorm and poststorm discrete samples were collected manually in precombusted amber glass bottles and transported on ice to the laboratory. Storm event samples were collected in acid washed HDPE bottles at intervals ranging from 2 to $24 \mathrm{~h}$ using a Sigma 900 autosampler (Hach, Loveland, CO) deployed adjacent to the filtered optical package intake at the watershed mouth. Samples were retrieved daily to minimize holding time, transferred to precombusted amber glass bottles and transported to the laboratory on ice where they were filtered through combusted $0.3 \mu \mathrm{m}$ glass fiber filters (Advantec MFS, Dublin, $\mathrm{CA}$ ) and refrigerated at $4^{\circ} \mathrm{C}$ until analysis. Total suspended 
solids (TSS) were determined gravimetrically on the filters [Clesceri et al., 1998].

[10] Dissolved organic carbon (DOC) samples were acidified to $\mathrm{pH} \sim 2$ with concentrated hydrochloric acid and measured with a Shimadzu TOC-V CSH total organic carbon analyzer (Kyoto, Japan) via high temperature combustion using a platinum catalyst. The accuracy and precision of the DOC analyzer was within $5 \%$ as indicated by internal standards (KHP) and replicates. Optical absorbance was measured between 200 and $750 \mathrm{~nm}$ on filtered samples in a $0.01 \mathrm{~m}$ quartz cuvette using a CARY-300 spectrophotometer within $48 \mathrm{~h}$ of collection. All sample spectra were referenced to a blank spectrum of deionized, carbon free water and are expressed as the absorption coefficient in units of $\mathrm{m}^{-1}$ by dividing the measured absorbance by the cuvette path length $(0.01 \mathrm{~m})$ and multiplying by a $\log$ transform coefficient of 2.303 [Green and Blough, 1994; Hu et al., 2002]. The amount of colored dissolved organic matter $(\mathrm{CDOM})$ within a water sample is commonly estimated by the absorption coefficient at $254 \mathrm{~nm}\left(\mathrm{a}_{254}\right)$ or $370 \mathrm{~nm}\left(\mathrm{a}_{370}\right)$. Although nitrate and iron species can absorb light in the lower UV range, they do not interfere with absorbance and FDOM measurements at this study site due to their low concentrations [Weishaar et al., 2003]. Spectral slope $\left(S_{290-350}\right)$, an indicator of DOM composition [Blough and Del Vecchio, 2002; Boss and Zaneveld, 2003], was calculated using a nonlinear least squares curve fitting technique on the spectral range of $290-350 \mathrm{~nm}$ by equation (2):

$$
a(\lambda)=a\left(\lambda_{\text {ref }}\right) * \exp \left[-S_{290-350} *\left(\lambda-\lambda_{\text {ref }}\right)\right]
$$

where $a(\lambda)$ is the absorption coefficient of colored DOM (CDOM) at wavelength, a $\left(\lambda_{\text {ref }}\right)$ is the CDOM absorption at reference wavelength, $\lambda_{\text {ref }}, 285 \mathrm{~nm}$ and $S_{290-350}$ is the slope fitting parameter, also referred to as the spectral slope coefficient. Although DOC normalized absorbance at $254 \mathrm{~nm}$ $\left(\mathrm{SUVA}_{254}\right)$ is presented here in units of $\mathrm{L} \mathrm{mg} \mathrm{C}{ }^{-1} \mathrm{~m}^{-1}$ to ease comparison with other studies, it is not equivalent in magnitude to specific UV absorption, which is the absorption coefficient $\left(\mathrm{a}_{254}\right)$ divided by DOC concentration [Hu et al., 2002].

[11] Fluorescence excitation-emission matrix spectra (EEMs) were collected in signal-ratio mode on filtered samples with a SPEX Fluoromax-4 spectrofluorometer (Horiba Jobin Yvon, NJ) using a $150 \mathrm{~W}$ Xenon lamp. Fluorescence intensity was measured at excitation wavelengths of 250 to 440 at $10 \mathrm{~nm}$ increments, and emission wavelengths of 300 to 600 at $5 \mathrm{~nm}$ increments on room temperature samples $\left(25^{\circ} \mathrm{C}\right)$ in a $0.01 \mathrm{~m}$ quartz cell. Raw fluorescence intensity data was Raman area normalized, instrument-specific bias corrected and blank subtracted [Jaffé et al., 2008; R. M. Cory et al., Effects of instrument-specific response on the analysis of fulvic acid fluorescence spectra, submitted to Limnology and Oceanography, 2008] prior to further analysis. For samples with an $\mathrm{A}_{254}$ value of greater than 0.03 , excitation and emission intensity corrections were applied to account for the inner filter effect [MacDonald et al., 1997]. Inner filter effect corrections were made using default Floromax-4 specific values supplied by the manufacturer (Cory et al., submitted manuscript, 2008). Using instrument specific values, rather than the classically assumed values improves IFE corrections [MacDonald et al., 1997]. Laboratory FDOM was calculated from the trapezoidal integration of corrected emission intensity from 400 to $520 \mathrm{~nm}$ at an excitation wavelength of $370 \mathrm{~nm}$ in order to more accurately compare to the wide emission band pass of the in situ WETStar fluorometers. The fluorescence emission peak for an excitation wavelength of $370 \mathrm{~nm}$ for all discrete lab samples fell within the spectral window from $460 \mathrm{~nm}$ to $465 \mathrm{~nm}$. Fluorescence index (FI) was calculated on corrected EEMs as the ratio of emission intensities at 470 and $520 \mathrm{~nm}$ at an excitation wavelength of $370 \mathrm{~nm}$ [Cory and McKnight, 2005].

\subsection{Laboratory Experiment}

[12] To assess the role of suspended sediments on unfiltered in situ FDOM measurements, we conducted a laboratory experiment measuring FDOM values in a solution of constant DOM but varying sediment concentration. The solution was created by mixing representative surface soils with filtered Willow Slough water, waiting until equilibrium was established, and then progressively filtering out sediments while continuously measuring FDOM and turbidity. Pasture soils used for the experiment (silt loam, 1.62\% C) were collected from the top $15 \mathrm{~cm}$ within our study catchment, air-dried and sieved prior to use. Filtered surface water was collected $72 \mathrm{~h}$ before the experiment at the mouth of the watershed during base flow conditions. Approximately $44 \mathrm{~g}$ of mineral soil was added to $20 \mathrm{~L}\left(2.2 \mathrm{~g} \mathrm{~L}^{-1}\right)$ of Willow Slough surface water and stirred periodically over a $48 \mathrm{~h}$ period. Equilibrium of carbon between the particulate and dissolved phase was inferred by negligible change in the absorption coefficients of filtered aliquots at $254 \mathrm{~nm}$ (data not shown). Experimental data were collected using a WETStar FDOM fluorometer and YSI 6136 to measure FDOM and turbidity, respectively, on a flow-through system. Alternating between filtered $(0.2 \mathrm{um})$ and unfiltered configurations via a bypass valve, the well mixed sample was pumped from a $20 \mathrm{~L}$ carboy through the instruments at turbidities of $500,330,200,90,50,25,9$, and approximately 0 FNU. Data in Figure 6 include results from both the field and lab experiment. The data are reported as a decrease in FDOM relative to the final filtered FDOM value ( $\sim 0 \mathrm{FNU}$ ) so that comparisons to field data could be made. Ancillary parameters including $\mathrm{pH}$, specific conductance (SC), dissolved oxygen, (DO), and water temperature were also measured and showed negligible change throughout the experiment.

\section{Results}

[13] The study period (15 February to 18 March 2008) was characterized by one rainfall period (Figure 2a), with a larger event on 22-24 February accounting for $78-82 \%$ of the total rainfall at the mouth $(4.0 \mathrm{~cm})$ and headwaters $(5.6$ $\mathrm{cm})$, respectively. Willow Slough discharge was relatively low prior to the storm $\left(\sim 0.5 \mathrm{~m}^{3} \mathrm{~s}^{-1}\right)$ and was dominated by groundwater discharge with high SC (Figure 2b). Discharge increased by nearly 2 orders of magnitude in response to rainfall and was characterized by a rapid rise to peak discharge $\left(37.9 \mathrm{~m}^{3} \mathrm{~s}^{-1}\right)$ and decrease to base flow conditions $\left(<0.50 \mathrm{~m}^{3} \mathrm{~s}^{-1} ;\right.$ Figure $\left.2 \mathrm{~b}\right)$. Calculated rainfall-runoff ratios for the storm event period (23-29 February) ranged 


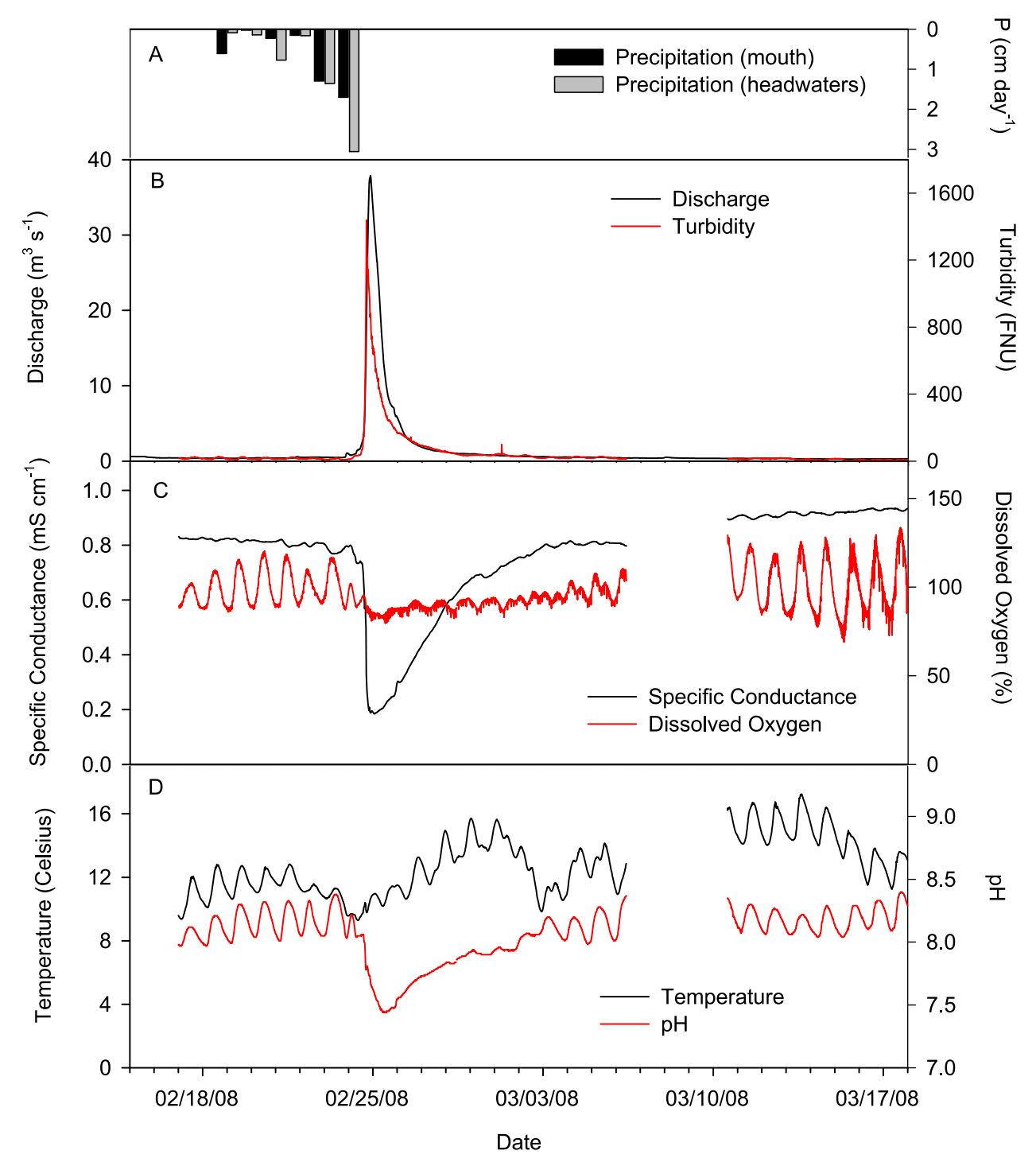

Figure 2. Precipitation and ancillary in situ measurements at the mouth of the Willow Slough watershed from 15 February to 18 March 2008 including (a) daily rainfall at the watershed mouth and headwaters $\left(\mathrm{cm} \mathrm{d}^{-1}\right),(\mathrm{b})$ discharge $\left(\mathrm{m}^{3} \mathrm{~s}^{-1}\right)$ and turbidity (FNU), (c) specific conductance $\left(\mathrm{mS} \mathrm{cm}^{-1}\right)$ and dissolved oxygen $(\%)$, and $(\mathrm{d})$ temperature $\left({ }^{\circ} \mathrm{C}\right)$ and $\mathrm{pH}$.

from approximately $6 \%$ in the agricultural valley of the watershed to $26 \%$ in the grassland headwaters, with a watershed average rainfall-runoff ratio of approximately $12 \%$ (data not shown).

\subsection{In Situ Data}

[14] In situ turbidity (correlated with TSS, $\mathrm{r}^{2}=0.80, p<$ 0.01; Table 1) increased rapidly with discharge from $50 \mathrm{FNU}$ to sensor saturation for $1 \mathrm{~h}(>1200 \mathrm{FNU})$ on 24 February (Figure 2b). Peak turbidity occurred $4 \mathrm{~h}$ before peak discharge and turbidity returned to base flow values ( $230 \mathrm{FNU})$ within 4 days. Values for SC decreased by nearly $80 \%$ ( 0.799 to $0.184 \mathrm{mS} \mathrm{cm}^{-1}$ ) over an $8 \mathrm{~h}$ period, reflecting the rapid dilution of preevent base flow and a prolonged return toward base flow values (Figure 2c). Temperature, $\mathrm{DO}$, and $\mathrm{pH}$ exhibited diurnal variability during preevent and postevent base flow, but the diurnal signal was reduced in all parameters during the storm period (Figures $2 \mathrm{c}, 2 \mathrm{~d}$, and 3 ).
[15] FDOM concentrations were comparable on both the filtered and unfiltered fluorometers at approximately $30 \mathrm{ppb}$ QSE prior to the rainfall event when turbidity averaged about 30 FNU and both signals showed weak diurnal variability (Figure 3). The FDOM response to the rainfall event resulted in a large increase in FDOM values (Figure 3) and revealed differences in magnitude and timing of change between the unfiltered and filtered fluorometers. Peak filtered FDOM concentrations reached $143 \mathrm{ppb}$ QSE and lagged behind peak turbidity and discharge by 15 and $11 \mathrm{~h}$, respectively (Figures $2 \mathrm{~b}$ and 3). The unfiltered FDOM concentrations peaked at values of $103 \mathrm{ppb}$ QSE and lagged the peak filtered FDOM concentrations by nearly $24 \mathrm{~h}$ (Figure 3 ). Filtered and unfiltered FDOM values converged on 27 February at FDOM values of $92 \mathrm{ppb}$ QSE (Figure 3; turbidity $=80 \mathrm{FNU}$ ), with a return to a diurnal signature in both systems in the latter part of the study period. 
Table 1. Laboratory Optical and Chemistry Data for Discrete Samples Collected at the Mouth of the Willow Slough Watershed

\begin{tabular}{|c|c|c|c|c|c|c|c|c|c|}
\hline Date & Time & $\begin{array}{c}\mathrm{TSS} \\
\left(\mathrm{mg} \mathrm{L}^{-1}\right) \\
\end{array}$ & $\begin{array}{c}\mathrm{DOC} \\
\left(\mathrm{mg} \mathrm{L}^{-1}\right) \\
\end{array}$ & $\begin{array}{c}\mathrm{SUVA}_{254} \\
\left(\mathrm{~L} \mathrm{mg}^{-1} \mathrm{C} \mathrm{m}^{-1}\right)\end{array}$ & $\begin{array}{l}\mathrm{a} 254 \\
\left(\mathrm{~m}^{-1}\right) \\
\end{array}$ & $\begin{array}{l}\mathrm{a} 370 \\
\left(\mathrm{~m}^{-1}\right) \\
\end{array}$ & $\begin{array}{c}\mathrm{S}_{290-350} \\
\left(\mathrm{~nm}^{-1}\right)\end{array}$ & $\mathrm{FI}(\mathrm{RU})$ & $\begin{array}{c}\text { FDOM } \\
(\mathrm{RU}) \\
\end{array}$ \\
\hline 20 Feb 2008 & 1300 & 21.85 & 2.37 & 2.23 & 0.053 & 0.009 & 0.017 & 1.64 & 19.52 \\
\hline 21 Feb 2008 & 1040 & 18.41 & 2.56 & 1.88 & 0.048 & 0.009 & 0.017 & 1.69 & 20.10 \\
\hline 21 Feb 2008 & 1340 & $\mathrm{ND}^{\mathrm{a}}$ & 2.47 & 2.20 & 0.054 & 0.010 & 0.017 & 1.63 & 19.71 \\
\hline 22 Feb 2008 & 0000 & 21.22 & 2.57 & 1.98 & 0.051 & 0.008 & 0.018 & 1.68 & 18.05 \\
\hline 22 Feb 2008 & 1200 & 23.30 & 2.73 & 2.05 & 0.056 & 0.009 & 0.018 & 1.70 & 18.53 \\
\hline 23 Feb 2008 & 1400 & 22.63 & 2.52 & 2.19 & 0.055 & 0.009 & 0.018 & 1.70 & 17.59 \\
\hline 23 Feb 2008 & 2000 & 15.59 & 2.66 & 2.22 & 0.059 & 0.010 & 0.018 & 1.66 & 19.23 \\
\hline 24 Feb 2008 & 0000 & 16.59 & 2.66 & 2.27 & 0.060 & 0.010 & 0.018 & 1.70 & 19.91 \\
\hline 24 Feb 2008 & 0400 & 28.75 & 2.53 & 2.23 & 0.056 & 0.010 & 0.018 & 1.71 & 19.08 \\
\hline 24 Feb 2008 & 0800 & 49.37 & 3.42 & 2.29 & 0.078 & 0.013 & 0.017 & 1.65 & 24.18 \\
\hline 24 Feb 2008 & 1200 & 92.09 & 3.23 & 2.38 & 0.077 & 0.015 & 0.016 & 1.69 & 24.62 \\
\hline 24 Feb 2008 & 1600 & 853.75 & 4.39 & 2.63 & 0.115 & 0.023 & 0.015 & 1.65 & 37.37 \\
\hline 24 Feb 2008 & 1800 & 756.60 & 5.25 & 2.67 & 0.140 & 0.028 & 0.015 & 1.62 & 44.23 \\
\hline 24 Feb 2008 & 2000 & 1528.90 & 8.80 & 3.71 & 0.326 & 0.076 & 0.013 & 1.54 & 74.46 \\
\hline 24 Feb 2008 & 2200 & 1042.80 & 8.92 & 3.67 & 0.327 & 0.075 & 0.014 & 1.53 & 75.04 \\
\hline 25 Feb 2008 & 0000 & 995.70 & 9.56 & 3.82 & 0.365 & 0.083 & 0.014 & 1.53 & 80.50 \\
\hline 25 Feb 2008 & 0200 & 339.33 & 9.35 & 3.82 & 0.357 & 0.081 & 0.014 & 1.52 & 78.37 \\
\hline 25 Feb 2008 & 0400 & 700.33 & 9.77 & 3.97 & 0.388 & 0.090 & 0.014 & 1.52 & 81.32 \\
\hline 25 Feb 2008 & 0600 & 616.00 & 9.82 & 3.89 & 0.382 & 0.088 & 0.013 & 1.52 & 80.79 \\
\hline 25 Feb 2008 & 1000 & 391.45 & 9.63 & 3.71 & 0.357 & 0.082 & 0.014 & 1.53 & 77.50 \\
\hline 25 Feb 2008 & 1140 & 357.38 & 9.67 & 4.07 & 0.393 & 0.093 & 0.013 & 1.53 & 81.50 \\
\hline 25 Feb 2008 & 1600 & 202.90 & 9.20 & 4.15 & 0.382 & 0.098 & 0.013 & 1.53 & 78.45 \\
\hline 25 Feb 2008 & 2000 & 210.00 & 9.29 & 3.66 & 0.340 & 0.077 & 0.014 & 1.54 & 74.46 \\
\hline 26 Feb 2008 & 0000 & 151.36 & 8.93 & 3.74 & 0.333 & 0.081 & 0.013 & 1.55 & 73.41 \\
\hline 26 Feb 2008 & 0800 & 153.03 & 9.08 & 3.32 & 0.301 & 0.066 & 0.014 & 1.55 & 69.77 \\
\hline 26 Feb 2008 & 1400 & 71.09 & 8.84 & 3.26 & 0.288 & 0.063 & 0.014 & 1.53 & 67.19 \\
\hline 27 Feb 2008 & 1430 & 79.08 & 6.95 & 3.34 & 0.232 & 0.052 & 0.014 & 1.54 & 57.97 \\
\hline 28 Feb 2008 & 1100 & 46.52 & 5.56 & 2.99 & 0.166 & 0.034 & 0.015 & 1.57 & 46.33 \\
\hline 3 Mar 2008 & 1300 & 28.49 & 3.12 & 2.47 & 0.077 & 0.013 & 0.017 & 1.65 & 21.56 \\
\hline 12 Mar 2008 & 1520 & 26.84 & 2.66 & 2.19 & 0.058 & 0.010 & 0.017 & 1.63 & 20.50 \\
\hline
\end{tabular}

${ }^{\mathrm{a}}$ No data.

\subsection{Relationships Between in Situ and Laboratory Optical Properties}

[16] Discrete TSS concentrations increased rapidly and similarly to discharge with peak concentrations 2 orders of magnitude above base flow values (Table 1). DOC concentration increased during the storm to nearly four times base flow concentrations and decreased to base flow levels with decreasing discharge (Table 1). Bulk DOM optical

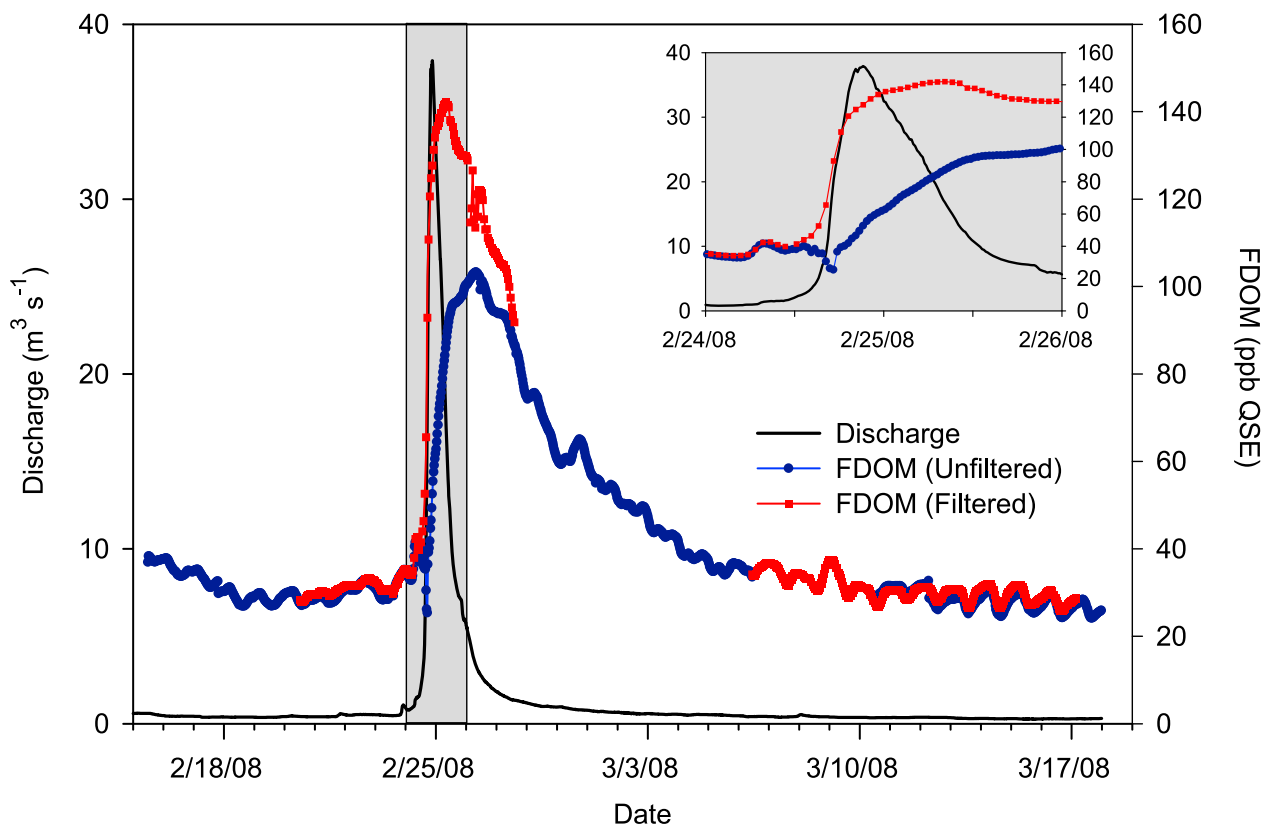

Figure 3. Time series of discharge $\left(\mathrm{m}^{3} \mathrm{~s}^{-1}\right)$ and in situ FDOM (ppb QSE) for the unfiltered and filtered fluorometers at the Willow Slough watershed mouth. Inset (covering gray region) is included to emphasize both the rapid increase of FDOM relative to the hydrograph as well as the rapid divergence between filtered and unfiltered FDOM measurements. 


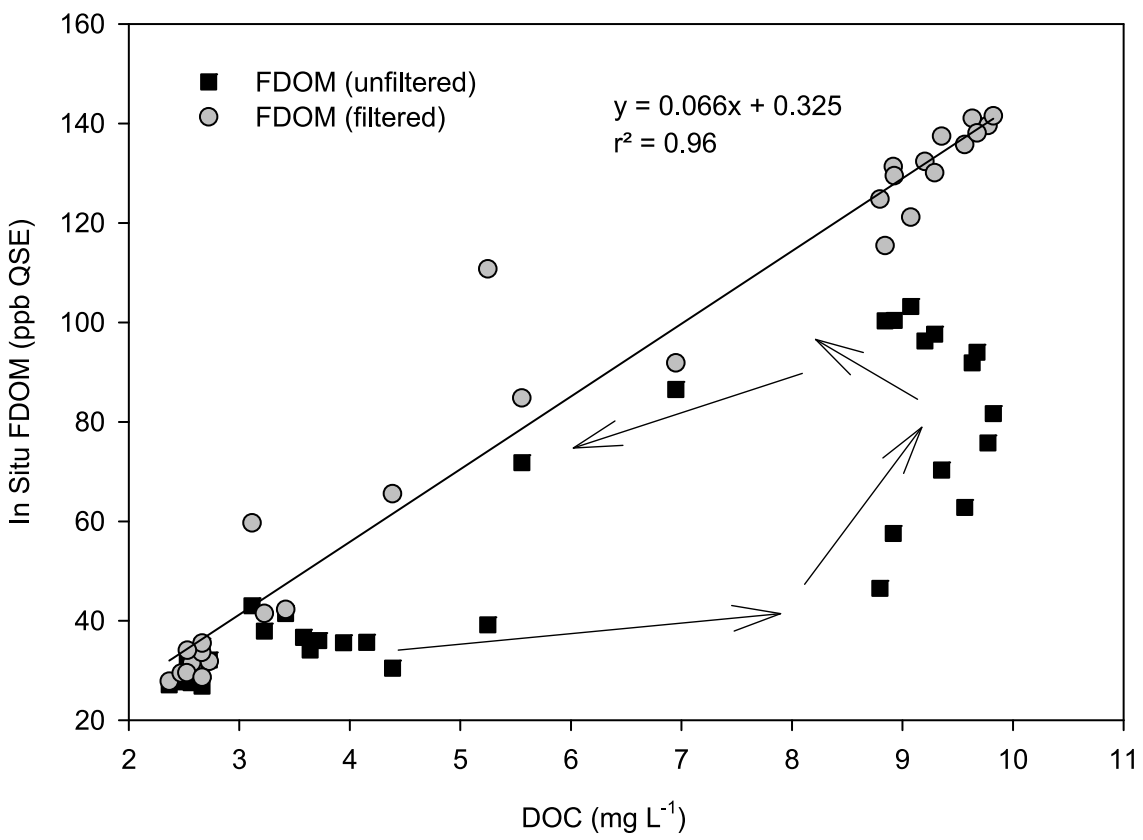

Figure 4. Relationship between DOC concentrations measured on discretely collected samples and in situ FDOM measurements from the unfiltered (black squares) and filtered (gray circles) WETStar fluorometer configurations. The filtered FDOM-DOC regression is shown as a black line, and arrows indicate the temporal progression (counterclockwise) of divergence between fluorescence intensity data reported by the filtered and unfiltered FDOM fluorometers.

properties, indicative of changes in DOM concentration and composition, also varied from base flow conditions during the storm event. The absorption coefficient at $254 \mathrm{~nm}, \mathrm{a}_{254}$, increased nearly an order of magnitude to a peak value of $90 \mathrm{~m}^{-1}$. SUVA 254 , an indicator of DOC aromaticity [Weishaar et al., 2003], increased by up to $50 \%$ during the storm event, while spectral slope $\left(\mathrm{S}_{290-350}\right)$, an indicator of relative changes in DOM molecular weight [Blough and Del Vecchio, 2002], decreased from 0.016 to 0.013 at peak FDOM concentration (Table 1). Fluorescence index (FI), an indicator of the relative contribution of microbial and terrestrial fulvic acids [McKnight et al., 2001], decreased from a preevent value of 1.68 to 1.51 at the FDOM peak (Table 1), returning toward preevent values by 3 March.

\subsection{Evaluation of in Situ FDOM Measurements}

[17] In situ FDOM from the filtered flow path instrument was strongly correlated $\left(\mathrm{r}^{2}=0.99\right)$ to laboratory FDOM measured on discrete samples throughout the range of flow conditions, while the unfiltered FDOM is not significantly correlated with lab FDOM (Table 1). Throughout the study period, DOC concentration is strongly correlated with filtered in situ FDOM concentrations $\left(\mathrm{r}^{2}=0.97\right.$, Figure 4). However, unfiltered in situ FDOM measurements versus DOC showed a counterclockwise hysteresis loop at the onset of increased turbidity ( $>100 \mathrm{FNU}$ ), returning to the line defined by filtered measurements toward the end of the storm event (Figure 4). The onset of the hysteresis is coincident with the deviation between unfiltered and filtered time series FDOM data (Figure 3). Optical compositional indicators $\left(\mathrm{SUVA}_{254}, S_{290-350}\right.$, and FI) were also strongly correlated $\left(\mathrm{r}^{2}=0.88-0.90\right)$ with in situ filtered FDOM values throughout the storm event (Figures $5 \mathrm{a}-5 \mathrm{c}$ ).
[18] Results from the laboratory study confirmed that turbidity affected the unfiltered FDOM measurements. Unfiltered FDOM values were 37\% lower than filtered FDOM values at the highest turbidities tested (500 FNU), and $8 \%$ lower at $50 \mathrm{FNU}$ (Figure 6). The relationship in the laboratory study generally fit the polynomial equation developed using in situ optical data corresponding to discrete sampling times (Figure 6). Field turbidity was strongly correlated with total suspended sediment concentrations $\left(\mathrm{TSS}\left(\mathrm{mg} \mathrm{L}^{-1}\right)=0.718 *\right.$ turbidity $(\mathrm{FNU})+31.07$, $\mathrm{r}^{2}=0.80$; data not shown) (Table 1). Both field and laboratory results show a similar, increasing relationship between turbidity and the percentage of underestimated FDOM relative to filtered values (Figure 6).

\section{Discussion}

\subsection{Storm Event DOM Concentration and Composition}

[19] DOC concentration varied between 2.37 to $9.82 \mathrm{mg}$ $\mathrm{L}^{-1}$ across the study period, with highest concentrations following peak discharge (Table 1). Other studies in small agricultural watersheds have also reported rapid and significant increases in DOC concentrations during storm events [Dalzell et al., 2005; Royer and David, 2005; Vidon et al., 2008], indicative of a mobilization of DOC from the landscape. Although the largest changes in DOC concentration in our study occurred over a period less than $24 \mathrm{~h}$, the range of concentrations are consistent with the minimum and maximum values reported by Hernes et al. [2008] for the entire 2006 water year at the same location as this study. DOC concentration was strongly correlated with DOM absorption at 254 and $370 \mathrm{~nm}\left(\mathrm{r}^{2}=0.98\right.$ and $\mathrm{r}^{2}=0.97$; 


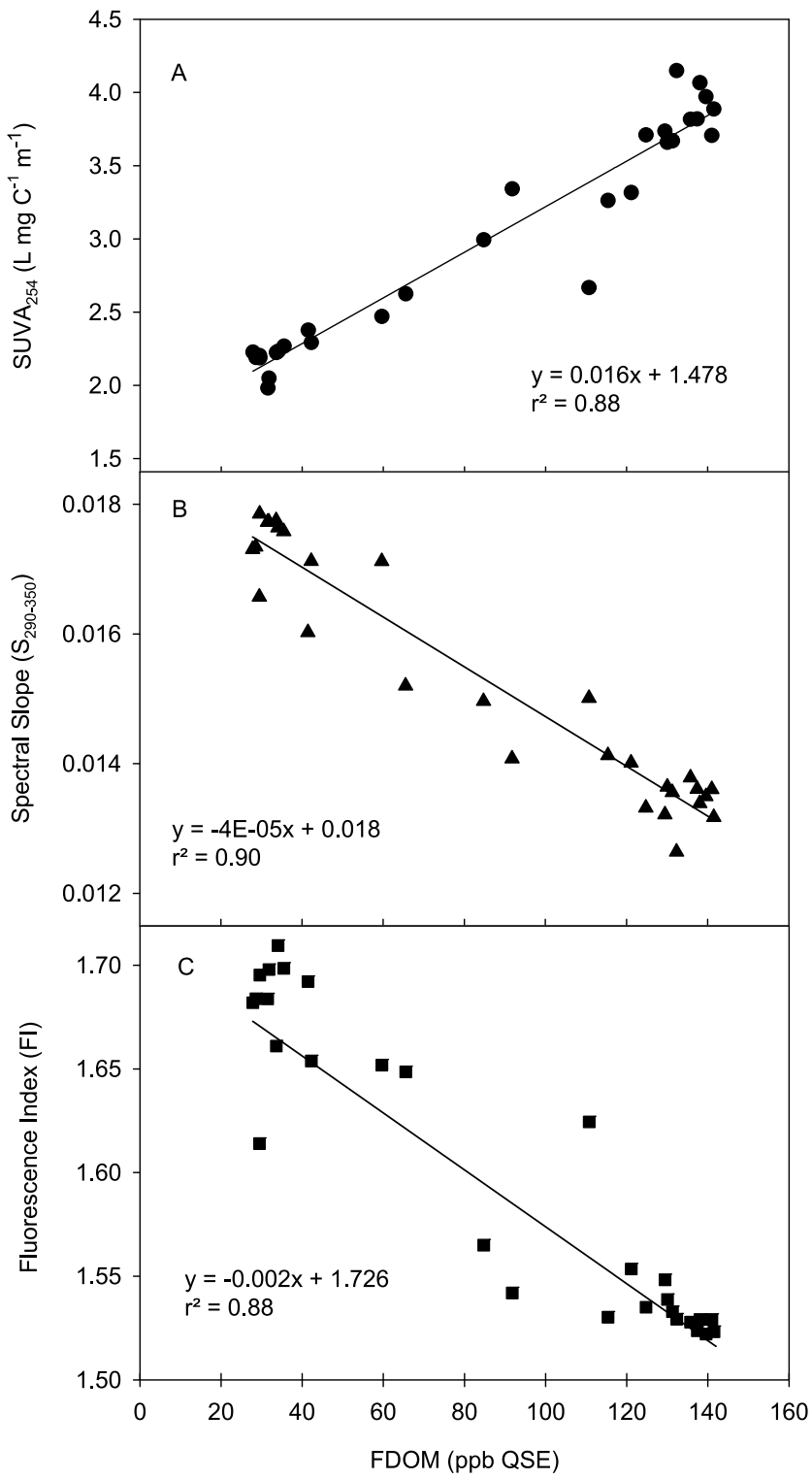

Figure 5. Relationship between in situ filtered FDOM (ppb QSE) and DOM compositional parameters, (a) SUVA254 (L $\mathrm{mg}^{-1} \mathrm{~m}^{-1}$ ), (b) spectral slope (S290-350, $\mathrm{nm}^{-1}$ ), and (c) fluorescence index (FI, unitless) from 20 February to 12 March 2008.

Table 1) and FDOM $\left(r^{2}=0.97\right)$ measured in the laboratory, indicating that both absorbance and fluorescence of filtered samples were good proxies for DOC concentration during the storm event (Table 1). The correlation between DOC concentrations and in situ filtered FDOM supports previous studies showing that peak C FDOM is a good predictor of DOC concentration in some surface waters [e.g., Vodacek et al., 1997; Belzile et al., 2006; Downing et al., 2009]. The prediction of DOC by peak C FDOM measurements may be limited to scenarios in which peak $\mathrm{C}$ is the dominant feature in the EEMs landscape. The utility of peak $\mathrm{C}$ in DOC prediction may break down when DOC changes are the result of changes in the quantity, for example, of amino acids relative to humic-like components. Given this potential limitation to terrestrial, humic rich environments, it is important to note that DOM is typically made up of $50 \%$ humic substances [Thurman, 1985].

[20] Laboratory optical parameters generally reflective of DOM source and character revealed changes over the study period. For example, an increase in SUVA 254 and decrease in $\mathrm{S}_{290-350}$ indicate an increase of higher molecular weight, aromatic-rich DOM [Chin et al., 1994]. While the absolute FI values $(1.52-1.70)$ are slightly higher than expected for terrestrial sources and should not to be used for quantitative source assessment, the decreasing FI values (Figure 5c) are indicative of a relative shift toward more terrestrially derived DOM during the event [McKnight et al., 2001]. Reasons for the seemingly high values are not presently understood, but may reflect the runoff of fresh plant leachates with a higher FI values than expected from more degraded terrestrial sources during the event. Similar compositional changes have been reported during hydrologic events in other agricultural watersheds [Dalzell et al., 2005; Vidon et al., 2008], which likely reflect a shift from groundwater flow paths to the rapid transport of DOM in surface runoff from organic-rich agricultural soils and steep headwater catchments. The observed increase in $\mathrm{SUVA}_{254}$ and decrease in $\mathrm{S}_{290-350}$ are consistent with previous data from Hernes et al. [2008] showing that higher vascular plant-derived DOM contributions occur during high-flow periods in Willow Slough in conjunction with more aromatic, higher molecular weight DOM. The lag of the FDOM peak relative to peak turbidity and discharge, as well as the delayed return to base flow FDOM values (Figure 4), suggests the relative importance of shallow soil drainage remains elevated for several days after the event.

[21] Hernes et al. [2008] also found a strong positive correlation between lignin concentration and TSS concentrations $\left(r^{2}=0.79\right)$ across hydrologic regimes in the Willow Slough watershed, with highest concentrations during winter storms and lowest during winter base flow. While this suggests that DOM composition may be influenced by sediment carbon transport and partitioning between the particulate and dissolved phase [Aufdenkampe et al., 2001; Hernes et al., 2007], the observed $15 \mathrm{~h}$ lag in peak filtered FDOM relative to peak turbidity suggests that particles and FDOM have different watershed sources (Figures $2 \mathrm{~b}$ and 3 ). The potential release of FDOM from sediments on the timescale of rapid hydrologic events deserves further attention, particularly given the implication that agricultural practices which mobilize large amounts of sediments could have far-reaching effects to downstream systems [Hernes et al., 2008]. Although rates of chemical desorption from sediments vary, rapid changes in water $\mathrm{pH}$ and SC could alter sediment-water equilibrium and increase the rate and magnitude of DOM desorption.

[22] Aside from compositional changes in DOM during storms, the longer time series reveals diurnal variability in FDOM during winter base flow periods prior to and after the storm event (Figure 4). Spencer et al. [2007] reported diurnal FDOM variability in the San Joaquin River watershed of up to $6 \mathrm{ppb}$ QSE during a summer period characterized by high algal production and high solar radiation. Periods before and several days after the storm event are representative of the winter base flow mode of the Willow Slough watershed. During this mode, surface water is characterized by low DOC concentrations and DOC quality parameters suggest 


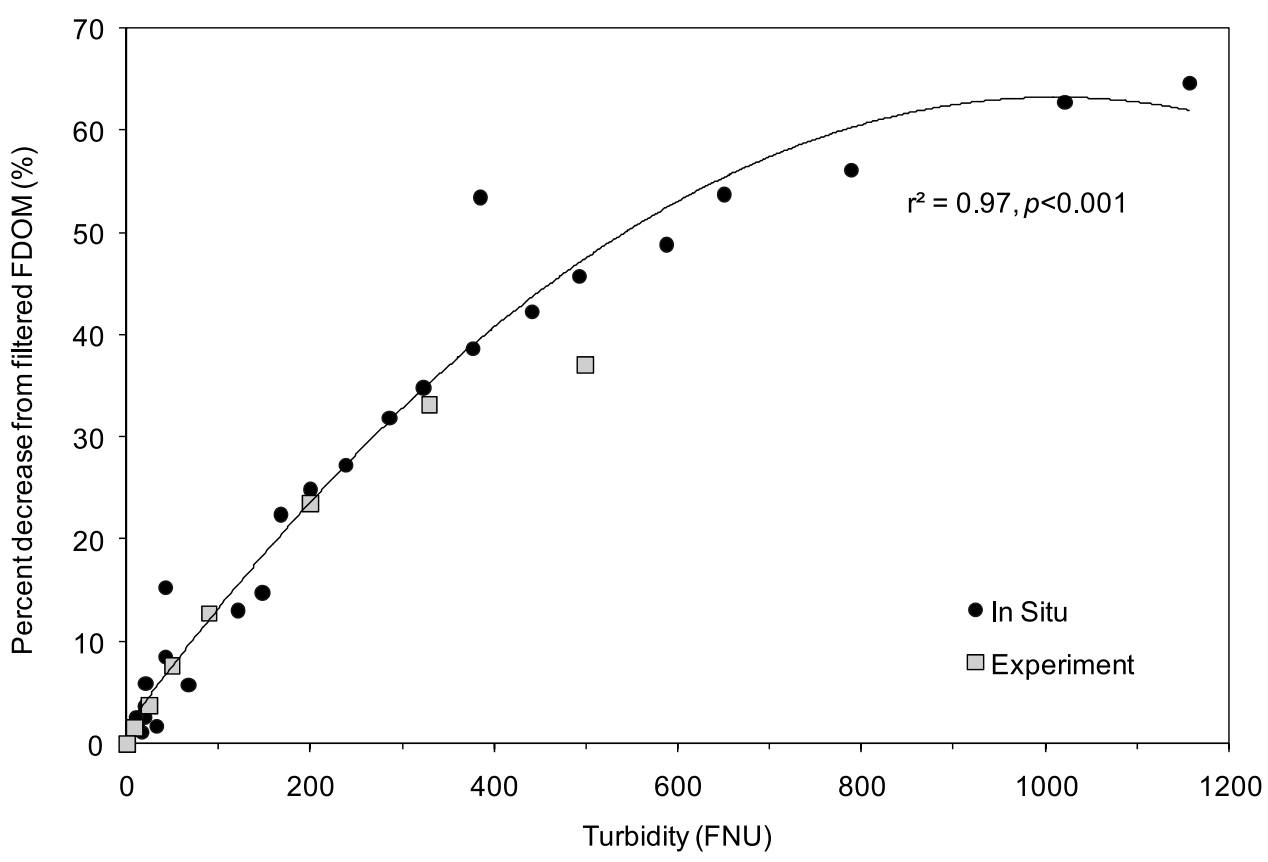

Figure 6. Relationship between turbidity (FNU) and the percent reduction in unfiltered FDOM relative to filtered FDOM of in situ storm data (black circles) and laboratory experiment data (gray squares). A polynomial fit is shown to illustrate the similarity in behavior of lab and field data, suggesting that particle concentration (as indicated by turbidity) is the controlling factor of the observed discrepancy in FDOM values.

the presence of less aromatic, lower molecular weight DOM, possibly of a microbial source (as inferred from $\mathrm{SUVA}_{254}$ and $\mathrm{S}_{290-350}$ and high FI values) in comparison to winter storm events or irrigation season runoff [Hernes et al., 2008]. The relative importance of algal versus groundwater DOM sources during winter base flow is not clear, although algal production (and possibly grazing by heterotrophic bacteria) is significant as indicated by diel DO variability and supersaturation (Figure 2) and low carbon normalized lignin yields [Hernes et al., 2008]. Together this evidence suggests that surface water DOC is a combination of both groundwater and algal source sources during winter base flow periods, potentially overprinted with degradation processes such as microbial grazing and photodegradation.

\subsection{Comparison of Filtered and Unfiltered FDOM Measurements}

[23] The optical measurement of dissolved matter requires that excitation and emmission irradiances are only altered by absorption of the excitation band and flourescence by the dissolved constituents, i.e., particles do not appreciably attenuate light or alter DOM spectral properties. However, Belzile et al. [2006] reported that suspended particles in concentrations up to $35 \mathrm{mg} \mathrm{L}^{-1}$ did not alter a linear relationship between unfiltered FDOM and CDOM $\left(\mathrm{a}_{370}\right)$ measurements in freshwater and coastal systems. The results of Belzile et al., however, may not be applicable to highly turbid waters typical of inland environments during storm events. In our study, FDOM estimated by both in situ fluorometers were comparable until turbidity levels increased rapidly from 100 to $1200 \mathrm{FNU}$ (Figure 6). This period overlaps with the greatest difference between filtered FDOM and unfiltered FDOM (up to $50 \%$ of the filtered value), indicating that suspended particles appreciably affect measurements of DOM fluorescence in unfiltered systems (Figures 3 and 4). The difference in filtered and unfiltered FDOM values has a number of implications for understanding the timing and magnitude of DOM transport during periods of high flux such as storms. For example, applying the FDOMDOC relationship in Figure 4 to both the filtered and unfiltered FDOM time series would result in a large difference in magnitude (332 versus $149 \mathrm{~g} \mathrm{C} \mathrm{s}^{-1}$, respectively) and $1.5 \mathrm{~h}$ lag in estimated instantaneous peak DOC flux (data not shown), indicating significant potential for underestimating the timing and magnitude of fluxes due to sediment interference.

[24] An underestimate of DOM fluorescence by the unfiltered system is not surprising since detritus and inorganic sediments are excellent scatterers and in certain cases, significant absorbers in the blue and UV wavelengths [Mobley, 1994; Belzile et al., 2002]. The relative components of light attenuation were not identified, but high particle scattering will direct light away from the detector, lengthen the optical path of photons that are detected and enhance the amount of lost light through particulate absorption. Therefore, the combined effects of scattering and absorption as a function of particle concentration are responsible for the FDOM underestimates using the unfiltered FDOM fluorometer. Given the dependence of turbidity measurements on particle size and character [Baker and Lavelle, 1984; Foster et al., 1992; Schoellhammer and Wright, 2003], site-specific relationships are likely neces- 
sary to assess the FDOM-turbidity relationship in other watersheds.

\section{Conclusions and Implications}

[25] The strong correlation between DOC concentration in discrete samples and in situ filtered FDOM measurements (Figure 5a) argues for the utility of in situ FDOM fluorometers as high-resolution DOC proxies in freshwater systems [Downing et al., 2009]. In situ FDOM measurements are particularly useful during short-duration episodic events such as storms where high-frequency measurements are necessary to capture rapid changes in water quality. Optical observatories such as the one used in this study are especially useful in monitoring DOM dynamics related to anthropogenic activities such as rapid changes in land use. When paired with discrete measurements, in situ data are useful for extending the insights of laboratory-based measurements that are more difficult and expensive to make. A combination of laboratory and in situ measurements was necessary to develop site-specific relationships between DOC and FDOM so that an accurate, high-resolution time series of DOC dynamics could be established. At our study site, the combination of in situ FDOM measurements with laboratory optical properties indicated a rapid storm-driven flux of high molecular weight, soil derived, humic-like DOM exiting the Willow Slough Watershed.

[26] Unfiltered optical systems have great appeal as in situ proxies for monitoring DOC dynamics without the cost and constraints of filtration, but their application during turbid storm events in many freshwater systems, particularly those systems influenced by human activity such as agriculture, may result in significant underestimates of FDOM and related variables such as DOC. The sediment concentration where this is an issue likely depends on particle size and composition [Foster et al., 1992], and errors in estimating accurate FDOM concentration of $>10 \%$ occurred at turbidities as low as $70 \mathrm{FNU}$ in our study (Figure 6). While corrections for particle interference are possible, site-specific relationships are likely necessary to assess the FDOM-turbidity relationship in other systems. Filtering can remedy interference problems but requires frequent service intervals to ensure a continuous record during times of high sediment flux. Approaches to maximizing useable filter life and minimizing gaps in the data record may include the use of modern programmable controllers coupled with real time monitoring.

[27] Acknowledgments. This project was funded by CALFED Drinking Water Program through a Proposition 50 grant. We thank Will Kerlin, Frank Anderson, Liz Beaulieu, Kathryn Crepeau, Cat Roush, Sarah Roush, and Sandrine Journet for laboratory and field support. We also thank Sandra Bachand and Travis Pritchard for flow data, as well as Roger Fujii, Peter Hernes, Rob Spencer, and Wayne Slade for helpful discussions. We also thank USGS reviewers Jamie Shanley, Scott A. Wright, and two anonymous reviewers for helpful suggestions that improved the quality of this manuscript. The use of brand names in this manuscript is for identification purposes only and does not imply endorsement by the U.S. Geological Survey.

\section{References}

Anderson, C. W. (2004), Turbidity, 2nd ed., U.S. Geol. Surv. Tech. Water Resour. Invest., 9(A6), section 6.7.

Aufdenkampe, A. K., J. I. Hedges, J. E. Richey, A. V. Krusche, and C. A. Llerena (2001), Sorptive fractionation of dissolved organic nitrogen and amino acids onto fine sediments within the Amazon Basin, Limnol. Oceanogr., 46, 1921-1935.
Baker, E. T., and J. W. Lavelle (1984), The effect of particle size on the light attenuation coefficient of natural suspensions, J. Geophys. Res., 89 , 8197-8203, doi:10.1029/JC089iC05p08197.

Belzile, C., W. F. Vincent, and M. Kumagai (2002), Contribution of absorption and scattering to the attenuation of UV and photosynthetically available radiation in Lake Biwa, Limnol. Oceanogr., 47, 95-107.

Belzile, C., C. S. Roesler, J. P. Christensen, N. Shakhova, and I. Semiletov (2006), Fluorescence measured using the WETStar DOM fluorometer as a proxy for dissolved matter absorption, Estuarine Coastal Shelf Sci., 67, 441-449, doi:10.1016/j.ecss.2005.11.032.

Blough, N. V., and R. Del Vecchio (2002), Chromophoric DOM in the coastal environment, in Biogeochemistry of Marine Dissolved Organic Matter, edited by D. Hansell and C. Carlson, pp. 509-546, Academic, San Diego, Calif.

Boss, E., and J. R. V. Zaneveld (2003), The effect of bottom substrate on inherent optical properties: Evidence of biogeochemical processes, Limnol. Oceanogr., 48, 346-354.

Chin, Y.-P., G. R. Aiken, and E. O’Loughlin (1994), Molecular weight, polydisperity, and spectroscopic properties of aquatic humic substances, Environ. Sci. Technol., 28, 1853-1858, doi:10.1021/es00060a015.

Clesceri, L. S., A. D. Eaton, and A. E. Greenberg (1998), Standard Methods for the Examination of Water and Wastewater, Am. Public Health Assoc., Washington, D. C.

Coble, P. G. (1996), Characterization of marine and terrestrial DOM in seawater using excitation-emission matrix spectroscopy, Mar. Chem., 51, 325-346, doi:10.1016/0304-4203(95)00062-3.

Coble, P. G. (2007), Marine optical biogeochemistry, Chem. Rev., 107, 402-418, doi: $10.1021 / \mathrm{cr} 050350+$.

Cory, R. M., and D. M. McKnight (2005), Fluorescence spectroscopy reveals ubiquitous presence of reduced and oxidized quinone moiety in dissolved organic matter, Environ. Sci. Technol., 39, 8142-8149, doi:10.1021/es0506962.

Dalzell, B. J., T. R. Filley, and J. M. Harbor (2005), Flood pulse influences on terrestrial organic matter export from an agricultural watershed, J. Geophys. Res., 110, G02011, doi:10.1029/2005JG000043.

Del Castillo, C. E., P. G. Coble, R. N. Conmy, F. W. Muller-Karger, L. Vanderbloemen, and G. A. Vargo (1999), Multispectral in-situ measurements of organic matter and chlorophyll fluorescence in seawater: Documenting the intrusion of the Mississippi River plume in the West Florida Shelf, Limnol. Oceanogr., 16, 1836-1843.

Downing, B. D., B. A. Bergamaschi, D. G. Evans, and E. Boss (2008), Assessing contribution of DOC from sediments to a drinking-reservoir using optical profiling, Lake Reservoir Manage., 24, 381-391, doi:10.1080/07438140809354848.

Downing, B. D., E. Boss, B. A. Bergamaschi, J. A. Fleck, M. A. Lionberger, N. K. Ganju, D. Shoellhamer, and R. Fujii (2009), Quantifying fluxes and characterizing compositional changes of dissolved organic matter in aquatic systems in situ using combined acoustic and optical measurements, Limnol. Oceanogr. Methods, 7, 119-131.

Foster, I. D., R. Millington, and R. G. Grew (1992), The impact of particle size controls on stream turbidity measurement: Some implications for suspended sediment yield estimation, IAHS Publ., 210, 51-62.

Green, S. A., and N. V. Blough (1994), Optical absorption and fluorescence properties of chromophoric dissolved organic matter in natural waters, Limnol. Oceanogr., 39, 1903-1916.

Hernes, P. J., A. C. Robinson, and A. K. Aufdenkampe (2007), Fractionation of lignin during leaching and sorption and implications for organic matter freshness, Geophys. Res. Lett., 34, L17401, doi:10.1029/ 2007GL031017.

Hernes, P. J., R. G. M. Spencer, G. Y. Dyda, B. A. Pellerin, P. A. M. Bachand, and B. A. Bergamaschi (2008), Hydrologic controls on dissolved organic carbon composition in an agricultural watershed, Geochim. Cosmochim. Acta, 72, 5266-5277, doi:10.1016/j.gca.2008.07.031.

Hood, E., M. N. Gooseff, and S. L. Johnson (2006), Changes in the character of stream water dissolved organic carbon during flushing in three small watersheds, Oregon, J. Geophys. Res., 111, G01007, doi:10.1029/ 2005JG000082.

Hu, C., F. E. Muller-Karger, and R. G. Zepp (2002), Absorbance, absorption coefficient, and apparent quantum yield: A comment on common ambiguity in the use of these optical concepts, Limnol. Oceanogr., 47, $1261-1267$

Jaffé, R., D. M. McKnight, N. Maie, R. M. Cory, W. H. McDowell, and J. L. Campbell (2008), Spatial and temporal variations in DOM composition in ecosystems: The importance of long-term monitoring of optical properties, J. Geophys. Res., 113, G04032, doi:10.1029/2008JG000683.

Kirchner, J. W., X. Feng, C. Neal, and A. J. Robson (2004), The fine structure of water-quality dynamics: The (high frequency) wave of the future, Hydrol. Process., 18, 1353-1359, doi:10.1002/hyp.5537.

MacDonald, B. C., S. J. Lvin, and H. Patterson (1997), Correction of fluorescence inner filter effects and the partitioning of pyrene to dissolved 
organic carbon, Anal. Chim. Acta, 338, 155-162, doi:10.1016/S00032670(96)00306-6.

McKnight, D. M., E. W. Boyer, P. K. Westerhoff, P. T. Doran, T. Kulbe, and D. T. Andersen (2001), Spectrofluorometric characterization of dissolved organic matter for indication of precursor organic matter and aromaticity, Limnol. Oceanogr., 46, 38-48.

Mobley, C. D. (1994), Light and Water: Radiative Transfer in Natural Waters, Academic, San Diego, Calif.

Royer, T. V., and M. B. David (2005), Export of dissolved organic carbon from agricultural streams in Illinois, USA, Aquat. Sci., 67, 465-471.

Schoellhammer, D. H., and S. A. Wright (2003), Continuous measurement of suspended-sediment discharge in rivers by use of optical backscatterance sensor, IAHS Publ., 283, 28-36.

Schuster, P. F., J. B. Shanley, M. Marvin-Dipasquale, M. M. Reddy, G. R. Aiken, D. A. Roth, H. E. Taylor, D. P. Krabbenhoft, and J. F. DeWild (2008), Mercury and organic carbon dynamics during runoff episodes from a northeastern USA watershed, Water Air Soil Pollut., 187, 89108, doi:10.1007/s11270-007-9500-3.

Spencer, R., B. A. Pellerin, B. A. Bergamaschi, B. D. Downing, T. E. C. Kraus, D. E. Smart, R. D. Dahlgren, and P. J. Hernes (2007), Diurnal variability in riverine dissolved organic matter composition determined by in situ optical measurement in the San Joaquin River (California, USA), Hydrol. Process., 21, 3181-3189, doi:10.1002/hyp.6887.

Thurman, E. M. (1985), Organic Geochemistry of Natural Waters, Kluwer Acad., Boston, Mass.

Twardowski, M. S., and P. L. Donaghay (2002), Photobleaching of aquatic dissolved materials: Absorption removal, spectral alteration and their interrelationship, J. Geophys. Res., 107(C8), 3091, doi:10.1029/1999JC000281.

van Verseveld, W. J., J. J. McDonnell, and K. Lajtha (2008), A mechanistic assessment of nutrient flushing at the catchment scale, J. Hydrol. Amsterdam, 358, 268-287, doi:10.1016/j.jhydrol.2008.06.009.
Vidon, P., L. E. Wagner, and E. Soyeux (2008), Changes in the character of DOC in streams during storms in two Midwestern watersheds with contrasting land uses, Biogeochemistry, 88, 257-270, doi:10.1007/s10533 008-9207-6.

Vodacek, A., N. V. Blough, M. D. Degrandpre, E. T. Peltzer, and R. K. Nelson (1997), Seasonal variation of CDOM and DOC in the middle Atlantic Bight; terrestrial inputs and photooxidation, Limnol. Oceanogr., $42,674-686$

Weishaar, J. L., G. R. Aiken, B. A. Bergamaschi, M. S. Fram, and K. Mopper (2003), Evaluation of specific ultraviolet absorbance as an indicator of the chemical composition and reactivity of dissolved organic carbon, Environ. Sci. Technol., 37, 4702-4708, doi:10.1021/ es030360x.

Williamson, C. E., D. P. Morris, M. L. Pace, and O. G. Olson (1999), Dissolved organic carbon and nutrients as regulators of lake ecosystems: Resurrection of a more integrated paradigm, Limnol. Oceanogr., 44, $795-803$.

Wilson, H. F., and M. A. Xenopolous (2009), Effects of agricultural land use on the composition of fluvial dissolved organic carbon, Nature Geosci., 2, 37-41, doi:10.1038/ngeo391.

P. A. M. Bachand, Bachand and Associates, 2023 Regis Dr., Davis, CA 95616, USA.

B. A. Bergamaschi, B. D. Downing, B. A. Pellerin, and J. F. Saraceno, U.S. Geological Survey, Placer Hall, 6000 J St., Sacramento, CA 95819 USA. (saraceno@usgs.gov)

E. Boss, School of Marine Sciences, University of Maine, 5741 Libby Hall, Orono, ME 04469, USA. 